\title{
Nonsense-mediated mRNA decay among human caspases: the caspase-2S putative protein is encoded by an extremely short-lived mRNA
}

\author{
Cell Death and Differentiation (2005) 12, 687-689. doi:10.1038/sj.cdd.4401594 \\ Published online 18 March 2005
}

\section{Dear Editor,}

Caspases are cystein proteases that play major roles in the initiation and propagation of apoptotic signals. ${ }^{1}$ Several human genes encoding caspases can undergo alternative mRNA splicing, which may lead to the production of shorter proteins. $^{2}$

Caspase-2 can function as both an initiator ${ }^{3}$ and an effector ${ }^{4}$ caspase, depending on the death stimulus and the cell type. The 12 exon-containing CASP-2 gene has been originally described to encode two isoforms with opposite roles in apoptosis. The long isoform, caspase-2L, is an ubiquitously expressed $48 \mathrm{kDa}$ protein that appears to be instrumental in the triggering of apoptosis, whereas the short isoform, caspase-2S, is a predicted $34 \mathrm{kDa}$ protein that can antagonize cell death when overexpressed. ${ }^{5}$ Synthesis of these proteins depends in part on an alternative mRNA splicing event occurring in the $3^{\prime}$ portion of the pre-mRNA. ${ }^{6}$ Exon 9, a $61 \mathrm{bp}$ sequence, is specifically inserted into caspase-2S mRNA, which leads to a premature stop codon at the very beginning of exon 10 . In addition, we have shown recently that the two caspase-2 isoforms originate from translation of distinct mRNA species that are initiated at separate locations within the promoter region of the CASP-2 gene. $^{7}$ Promoter selection involves insertion of distinct noncoding first exons, whereas the translation initiation codon, located within the second exon, is the same for both isoforms. Whether the caspase-2S isoform exists as a protein in human cells remains a confusing issue. In addition to the $48 \mathrm{kDa}$ long isoform, Western blot analysis of caspase-2 sometimes reveals a $33 \mathrm{kDa}$ product, which is likely a proteolytic product of caspase-2L, rather than the caspase$2 \mathrm{~S}$ protein.

We observed that the premature stop codon in caspase-2S mRNA was located within the theoretical limits imposed by the rule of nonsense-mediated mRNA decay (NMD). This active mRNA degradation process occurs when translation terminates more than 50-55 nucleotides upstream of the last intron-exon junction, ${ }^{8}$ upon recruitment of UpF proteins. ${ }^{9}$ The premature caspase-2S stop codon is located at the very beginning of exon 10, for example, more than 55 nucleotides upstream of the last intron-exon junction, whereas the stop codon for the caspase-2L protein is in the last exon.

We sought to look at the possibility that caspase-2S mRNA could be subjected to NMD, an event that can be readily determined from the analysis of mRNA half-life in the presence of the translation inhibitor cycloheximide. ${ }^{10}$ First, we quantified caspase-2L and caspase-2S relative mRNA levels by real-time PCR analysis in a panel of human cell lines. The average caspase-2L/-2S mRNA ratio was always high, that is, above 100-fold in several cell lines including leukemic cells (U937, KG1), carcinoma cells (HeLa, HCT116, HepG2, HT29) and immortalized cells (293T, Chang) (data not shown). These observations were in accordance with previous studies demonstrating the low expression of caspase-2S mRNA in tissues. ${ }^{11}$

We next treated cells for $2 \mathrm{~h}$ with cycloheximide before inhibiting mRNA synthesis by exposure to actinomycin $D$ for up to $3 \mathrm{~h}$. Caspase-2S and caspase-2L mRNA levels were analyzed by RT-PCR at various time points after the addition of actinomycin D (Figure 1a). In HeLa, U937 and 293T cells, cycloheximide induced accumulation of caspase-2S mRNA, suggesting a very short-lived mRNA, without affecting exon 9lacking caspase-2L mRNA. No further increase in caspase-2S mRNA was detected in the $3 \mathrm{~h}$ following actinomycin D addition (Figure 1a). These results, which were confirmed in KG1, THP-1, HCT116, HT29 and Chang cells, strongly suggest that caspase-2S mRNA is subjected to NMD. Similar observations were made by specific RT-PCR analysis of the 5 -end of caspase-2 transcripts (data not shown). The effect of cycloheximide was very rapid, that is, caspase-2S mRNA level increase was observed as soon as $15 \mathrm{~min}$ after the beginning of cycloheximide treatment (Figure 1b), the maximum induction level being reached after 105-120 min. In addition, the use of actinomycin $D$ either $2 \mathrm{~h}$ before that of cycloheximide or at the same time was also associated with increased exon 9 inclusion (data not shown). The protein synthesis blockade was found to reach 88,92 and $96.8 \%$ after 15,60 and 120 min of cycloheximide treatment, respectively. Very similar observations were made with the use of emetine, another translation inhibitor (Figure 1c). Altogether, these results suggest that the primary trigger of caspase-2S mRNA instability is a protein with a very short half-life, the identity of which will have to be determined in future studies.

Based on overexpression experiments, the short isoform of caspase-2 was proposed to antagonize apoptosis. ${ }^{5}$ From some of these in vitro results, accelerated death of facial motor neurons observed in vivo during the development of 
a

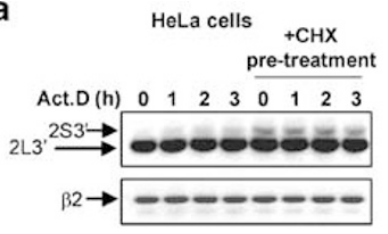

U937 cells

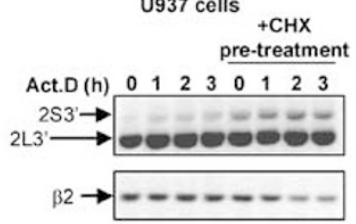

293T cells pre-treatment

Act.D (h) $\begin{array}{lllllll}0 & 1 & 2 & 3 & 0123 \\ 0\end{array}$

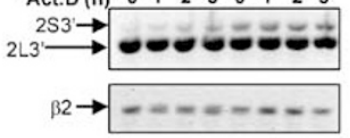

b

HeLa cells

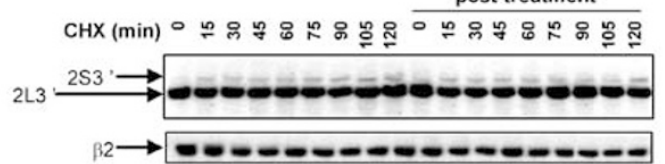

+ Act. D post-treatment

c

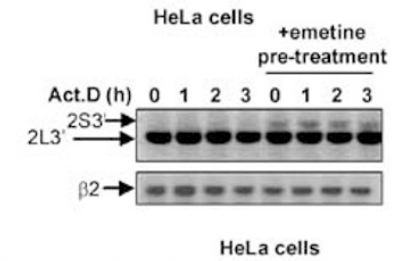

Emetine $(\min ) \stackrel{2 \mathrm{~L} 3 \mathrm{\circ} \longrightarrow \mathrm{\circ} \rightarrow}{\longrightarrow}$

e d U937 cells

$+\mathrm{CHX}$

Act.D (h) $\begin{array}{lllllll}0 & 2 & 3 & 0123\end{array}$

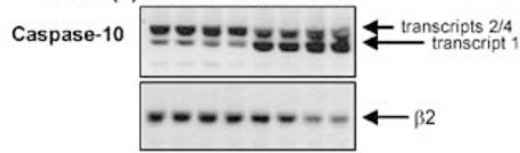

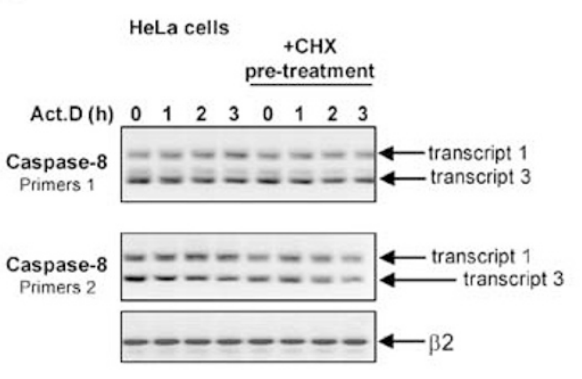

Figure 1 (a) Analysis of caspase-2 mRNA stability in HeLa, U937 and 293T cells. The human leukemic U937 cell line was maintained in RPMI 1640 (Roswell Park Memorial Institute, Gibco BRL, Cergy-Pontoise, France) supplemented with 10\% (v/v) fetal calf serum (FCS) (BioWhittaker, Fontenay-sous-bois, France). The human cervix cancer HeLa cell line was maintained in EMEM supplemented with 10\% (v/v) FCS and $2 \mathrm{mM} \mathrm{L-glutamine.} \mathrm{The} \mathrm{human} \mathrm{fetal} \mathrm{kidney} 293 \mathrm{~T}$ cell line was maintained in a 1/1 mixture of DMEM (Dulbecco's minimum essential medium, Gibco BRL) containing $1 \mathrm{~g} / \mathrm{g}$ glucose and HAM'S F10 (BioWhittaker) supplemented with $5 \%$ (v/v) FCS and $2 \mathrm{mM} \mathrm{L-glutamine.} \mathrm{All} \mathrm{cell} \mathrm{lines} \mathrm{were} \mathrm{obtained} \mathrm{from} \mathrm{the} \mathrm{ATCC} \mathrm{(Rockville,} \mathrm{MD,} \mathrm{USA).} \mathrm{To} \mathrm{ensure} \mathrm{exponential} \mathrm{growth,} \mathrm{cells} \mathrm{were} \mathrm{resuspended} \mathrm{or} \mathrm{replated} \mathrm{in} \mathrm{fresh}$ medium $24 \mathrm{~h}$ before each treatment performed at the cell density of $10^{6} / \mathrm{ml}$ or $10^{6} /$ Petri dish, for cells growing in suspension and adherent cells, respectively. Cells were incubated or not for $2 \mathrm{~h}$ in the presence of cycloheximide (CHX, $10 \mu \mathrm{g} / \mathrm{ml}$ ) prior to actinomycin D (Act.D, $5 \mu \mathrm{g} / \mathrm{ml})$ treatment (1-3h). Caspase-2 mRNA was analyzed by RT-PCR ('One-Step RT-PCR' kit, Qiagen, Courtaboeuf, France) using hICH1-e7s (5'-GTTACCTGCACACCGAGTCACG-3') and hICH1-e10as (5'GCGTGGTTCTTTCCATCTTGTTGGTCA-3') primers. $\beta 2$-Microglobulin (amplified with $5^{\prime}$-CTCACGTCATCCAGCAGAGA-3' and $5^{\prime}$-TCTTTTTCAGTGGGGGTGAA$3^{\prime}$ ) mRNA was used as a standardizing control. The experiment is representative of at least three independent analyses with similar results. (b) Kinetics of the effect of a pretreatment with $\mathrm{CHX}(10 \mu \mathrm{g} / \mathrm{ml})$ for indicated minutes on caspase-2 mRNA stability in HeLa cells, followed or not by a treatment with actinomycin D (Act.D, $5 \mu \mathrm{g} / \mathrm{ml}$, 2h). Caspase-2 mRNA was analyzed by RT-PCR using hICH1-e7s and hICH1-e10as primers. $\beta 2$-Microglobulin mRNA was used as a standardizing control. Incorporation of ${ }^{35} \mathrm{~S}$-Met into proteins was reduced by 88,92 and $96.8 \%$, following treatment with cycloheximide for 15,60 and 120 min, respectively. (c) Analysis of caspase-2 mRNA stability in HeLa cells. Cells were incubated or not for $2 \mathrm{~h}$ in the presence of emetine dihydrochloride hydrate $(4 \mu \mathrm{g} / \mathrm{ml}, 2 \mathrm{~h})$ prior to actinomycin D (Act. $\mathrm{D}, 5 \mu \mathrm{g} / \mathrm{ml}$ ) treatment (1-3h) (upper part). The kinetics of the effect of emetine dihydrochloride hydrate $(4 \mu \mathrm{g} / \mathrm{ml})$ for the indicated times (min) is shown (lower part). Caspase-2 mRNA was analyzed by RT-PCR using hICH1-e7s and hICH1-e10as primers. $\beta 2$-Microglobulin mRNA was used as a standardizing control. (d) Analysis of caspase-10 mRNA stability in U937 cells. See legend to (a). Caspase-10 mRNA was analyzed by RT-PCR using C10E5-s (5'-GGCAAAATAAGCATGCAGGT-3') and C10E7-as (5'-CAGGGCTGTGAAGTGAGACA-3') primers. Induction kinetics were similar to those observed for caspase-2S mRNA (data not shown). (e) Analysis of caspase-8 mRNA stability in HeLa cells. See legend to (a). Caspase-8 mRNA was analyzed by RT-PCR using C8E6-s1 (5'-GGAGGAGTTGTGTGGGGTAA-3') and C8E8-as1 (5'-GGGGCTTGATCTCAAAATGA-3') (primers 1) or C8E6-s2 (5'-CAGCAGCCTTGAAGGAAGTC-3') and C8E8-as2 (5'-GGGGCTTGATCTCAAAATGA-3') (primers 2) primers

caspase- $2^{-/}$mice was interpreted as the consequence of caspase-2S isoform deletion in this specific cell type. ${ }^{11}$ Nevertheless, no evidence was provided of detectable levels of caspase-2S protein in normal tissues and transformed cells. The demonstration that caspase-2S mRNA is subjected to NMD may indicate that the protein is usually not expressed or at very low level. However, since NMD can occur in a tissue-specific manner, ${ }^{12}$ we cannot rule out the possibility that caspase-2S protein may be expressed at selected developmental stages or in specialized mature cells.

We then performed a survey of 23 transcripts from eight human caspase genes in a search for other caspase mRNA species that could be subjected to NMD. In addition to caspase-2S mRNA, a possible NMD signature was identified in one caspase-8 and one caspase-10 mRNA species (Table 1). Exposure to cycloheximide for $2 \mathrm{~h}$ induced an important accumulation of caspase-10 transcript \# 1 (Figure 1d), regardless of the presence of actinomycin D. Kinetic analysis showed that the effect of cycloheximide was as rapid as in the case of caspase-2 mRNA (data not shown).
Similarly, emetine also triggered a strong and rapid increase in caspase-10 transcript \# 1 accumulation (data not shown). These results suggest that caspase-10 transcript \# 1 is also subjected to NMD. By analyzing various human cell lines, some authors identified the $31.4 \mathrm{kDa}$ caspase-10c protein isoform that could correspond to caspase-10 transcript \# $1,{ }^{13}$ whereas others did not. ${ }^{14}$ The size of the protein makes it undistinguishable from that of cleavage products of procaspase-10a or $-10 \mathrm{~d}$ corresponding to transcripts \# 2 and 4 , respectively (Table 1), but our results suggest that caspase10 transcript \# 1 is unlikely to allow sustained protein expression. By contrast, cycloheximide did not affect the expression of caspase-8 transcript \# 1, whose sequence suggested a possible regulation by NMD, nor that of caspase8 transcript 3 used as a negative control. The lack of caspase8 transcript \# 1 NMD was confirmed by using two distinct sets of primers (Figure 1e), suggesting that this transcript may correspond to an exception to the rule.

Taken together, our results strongly suggest that the antiapoptotic functions of the caspase-2S protein isoform 
Table 1 NMD candidates among human caspase transcripts

\begin{tabular}{|c|c|c|c|c|}
\hline & Ensembl Transcript ID & RefSeq ID & Short name & NMD candidate \\
\hline CASP1 & $\begin{array}{l}\text { ENST00000260309 } \\
\text { ENST00000260310 } \\
\text { ENST00000278626 } \\
\text { ENST00000278627 }\end{array}$ & $\begin{array}{l}\text { NM_033294 } \\
\text { NM_033295 }\end{array}$ & & $\begin{array}{l}\text { No } \\
\text { No } \\
\text { No } \\
\text { No }\end{array}$ \\
\hline CASP2 & $\begin{array}{l}\text { ENST00000222868 } \\
\text { ENST00000310447 } \\
\text { ENST00000337136 }\end{array}$ & & & $\begin{array}{l}\text { Yes } \\
\text { No } \\
\text { No }\end{array}$ \\
\hline CASP3 & $\begin{array}{l}\text { ENST00000296745 } \\
\text { ENST00000308394 }\end{array}$ & & & $\begin{array}{l}\text { No } \\
\text { No }\end{array}$ \\
\hline CASP6 & $\begin{array}{l}\text { ENST00000265164 } \\
\text { ENST00000285333 }\end{array}$ & NM_032992 & & $\begin{array}{l}\text { No } \\
\text { No }\end{array}$ \\
\hline CASP7 & $\begin{array}{l}\text { ENST00000298700 } \\
\text { ENST00000298701 }\end{array}$ & NM_033340 & & $\begin{array}{l}\text { No } \\
\text { No }\end{array}$ \\
\hline CASP8 & $\begin{array}{l}\text { ENST00000264274 } \\
\text { ENST00000264275 } \\
\text { ENST00000303385 } \\
\text { ENST00000323492 }\end{array}$ & $\begin{array}{l}\text { NM_033357 } \\
\text { NM_033358 }\end{array}$ & $\begin{array}{l}\text { Casp8-T1 } \\
\text { Casp8-T2 } \\
\text { Casp8-T3 } \\
\text { Casp8-T4 }\end{array}$ & $\begin{array}{l}\text { Yes } \\
\text { No } \\
\text { No } \\
\text { No }\end{array}$ \\
\hline CASP9 & $\begin{array}{l}\text { ENST00000255256 } \\
\text { ENST00000333868 }\end{array}$ & NM_032996 & & $\begin{array}{l}\text { No } \\
\text { No }\end{array}$ \\
\hline CASP10 & $\begin{array}{l}\text { ENST00000237865 } \\
\text { ENST00000272879 } \\
\text { ENST00000286186 } \\
\text { ENST00000313728 }\end{array}$ & $\begin{array}{l}\text { NM_032976 } \\
\text { NM_032977 }\end{array}$ & $\begin{array}{l}\text { Casp10-T1 } \\
\text { Casp10-T2 } \\
\text { Casp10-T3 } \\
\text { Casp10-T4 }\end{array}$ & $\begin{array}{l}\text { Yes } \\
\text { No } \\
\text { No } \\
\text { No }\end{array}$ \\
\hline
\end{tabular}

Caspase transcript data are as reported in the Ensembl Genome Server (http://www.ensembl.org). Potential NMD candidates were identified by analyzing the position of the translational stop codon

and of the caspase-10c protein isoform should be readdressed critically by taking into account the possibility that these isoforms are usually not expressed or expressed at very low levels. Nevertheless, NMD appears to be rare among human caspase mRNAs, suggesting that the majority of alternatively produced protein isoforms harbor selective functions.

\section{Acknowledgements}

S Solier was appointed by the University Hospital, Dijon. E Logette was a recipient of a fellowship from the Ministry of Research and Education. This work was supported by the Ligue Nationale Française Contre le Cancer, the Ligue Départementale Contre le Cancer (Saône \& Loire Comittee), the Conseil Général de Bourgogne and the INSERM. We wish to thank Drs. J Tazi, J Soret and JP Pais de Barros for helpful suggestions.

S Solier ${ }^{1,2}$, E Logette $^{1}$, L Desoche $^{1}$, E Solary $^{1}$ and $L \operatorname{Corcos}^{*, 3}$

1 INSERM U517, Faculté de médecine, 7, Bd Jeanne d'Arc, 21033 Dijon Cedex, France
2 Service d'hématologie clinique, CHRU le Bocage, 2, Bd Jeanne d'Arc, 21000 Dijon, France

3 INSERM U613/EA948, Faculté de Médecine, 22, Avenue Camille Desmoulins, 29238 Brest Cedex 3, France

* Corresponding author: L Corcos, INSERM U613/EA948, Faculté de Médecine, 22, Avenue Camille Desmoulins, 29238 Brest Cedex 3, France.

Tel: + 33-2-98-01-83-01; Fax: 33-2-98-01-83-22;

E-mail: laurent.corcos@univ-brest.fr

1. Budihardjo I et al. (1999) Annu. Rev. Cell Dev. Biol. 15: 269-290

2. Jiang ZH and Wu JY (1999) Proc. Soc. Exp. Biol. Med. 220: 64-72

3. Droin N et al. (2001a) Blood 97: 1835-1844

4. Slee EA, Adrain C and Martin SJ (1999) Cell Death Differ. 6: 1067-1074

5. Droin $\mathrm{N}$ et al. (2001b) Oncogene 20: 260-269

6. Solier S et al. (2004) Mol. Cancer Res. 2: 53-61

7. Logette E et al. (2003) Oncogene 22: 935-946

8. Nagy E and Maquat LE (1998) Trends Biochem. Sci. 23: 198-199

9. Singh $G$ and Lykke-Andersen J (2003) Trends Biochem. Sci. 28: 464-466

10. Sureau A et al. (2001) EMBO J. 20: 1785-1796

11. Bergeron L et al. (1998) Genes Dev. 12: 1304-1314

12. Bateman JF et al. (2003) Hum. Mol. Genet. 12: 217-225

13. Sprick MR et al. (2002) EMBO J. 21: 4520-4530

14. Kischkel FC et al. (2001) J. Biol. Chem. 276: 46639-46646 